\title{
Prospective Teachers' Beliefs about Problem Solving in Multiple Ways
}

\author{
Elif Esra Arikan \\ Faculty of Education, Sabahattin Zaim University, Turkey
}

Copyright $\bigcirc 2016$ by authors, all rights reserved. Authors agree that this article remains permanently open access under the terms of the Creative Commons Attribution License 4.0 International License

\begin{abstract}
The purpose of this study is to analyze whether prospective teachers believe solving a mathematics problem involves in using different solution methods. 60 mathematics prospective teachers who take the pedagogic training program in a state university were participated in this study. Five open-ended questions were asked. The study was carried out by collecting data through interviews among qualitative research methods and content analysis technique through analyzing the data. The study started with a pre-implementation. In pre-implementation, prospective teachers solved a geometry problem at class with multiple methods and then they exchanged their ideas with each other. Findings of the study revealed that while $90 \%$ of the prospective teachers stated that they believe the importance of solving problems with multiple methods, $10 \%$ of them stated that they preferred solving many problems with a single method rather solving a problem by using multiple methods.
\end{abstract}

Keywords The Prospective Teachers' Beliefs, Problem-solving, Solving Problems by Using Multiple Methods, Central Examinations in Turkey

\section{Why the Teachers' Beliefs Are Important?}

One of the most important factors that determine the relationship between the teacher and the student is the teachers' beliefs which affect conducting teaching and the teaching style of the teacher. It is because of the fact that people's beliefs are the key elements which directs his/her behaviors [2], [4], [10]. All the teachers; have beliefs on their students, subject fields, roles and responsibilities. These beliefs affect their perceptions and judgements and then their perceptions and judgements affect their behaviors in the classroom [16].

According to Yero [23], beliefs are defined as the perceptions, judgements and evaluations which he/she made and obtained in connection with the world around him/her, others or oneself. Besides, beliefs are to evaluate the reason or meaning of specific events through generalizations.

The teachers' beliefs about teaching and learning affect their theoretical tendencies, teaching practice that they are using in teaching process [3], their teaching plans, the selection of the activity types that they will carry out with students [9]. In other words, it is possible to say that the teachers' beliefs directly affect the things that students will learn [5], [15].

Based on these studies, the aim of this research is to examine that the participants' beliefs about solving a mathematics problem in multiple way.

\section{Problem Solving}

Problem can be defined as a difficulty which should be overcome or a newly encountered and complicated issue requiring mental focusing which an individual cannot predict how to find a solution about it at first [6], [18].

Problem solving is an ability which is needed to be improved for maintaining the existence of human beings as it is an activity needed in every part of life [19].

The curiosity mostly develops in childhood on its own and these ages are the time when learning occurs naturally [7]. In order to develop problem solving skills, it is expected from an individual to be; open-minded, curious and has the patience to do a research in depth. For this reason, problem solving skill is expected to be acquired starting from childhood.

Problem solving is a process [21]. In studies about education, the importance of problem solving is emphasized and the necessity of conducting problem solving activities according to each grade level is highlighted. Because one of the most important objectives of education is make students cope with the probable problems that he/she may encounter in the future.

Problem solving is defined as a skill which requires mental mastery [8]. When problem is thought as the difficulty which an individual encounter on its own, the individual should use authentic methods or his/her features 
like creative ideas and high level thinking abilities for problem solving [20].

The factors which are affecting problem solving skills are stated as; the attitude developed against problem, understanding, reasoning and experience. In order to improve problem solving skills, it is expected from an individual to have the skills of comparing and contrasting abilities together with flexible, critical, creative thinking and communication skills [22].

Leikin said that solving a mathematics problem by using multiple methods can be described as instructive and a tool for diagnosing creativity [12]. Krutetskii pointed out that multiple solution methods can be used in a problem as a diagnostic tool for creativity [11]. In other words, using multiple solution methods both improves creativity and also can be used as a tool for diagnosing creativity. For example, if one of the participants in the sample gets the solution by using a different method than others, it can be said that this participant has more developed creativity skills than the other participants.

\section{Problem Solving in Turkey}

In many educational systems, while problem solving is positioned at the center of teaching mathematics; problem solving in Turkey is considered as independent from everyday life and a separate topic in mathematics lessons [21]. Students are expected to write verbal expressions into mathematical language.

Students are elected and placed by Student Selection and Placement Centre (SSPC) with a central university entrance examination in Turkey. In these examinations, the knowledge of students regarding Turkish grammar, basic mathematics, science and social sciences lectured in high school problem is tested. Students are getting prepared to these examinations by solving questions both at school and private courses for being successful to enter universities. As the exam is conducted by using multiple choice questions, students pay attention to solve as many questions as they can solve. Testing strategies are very important for this examination. Therefore, it is mentioned from an examination in which students look for the shortest way to find the answers rather than the solution methods of the questions. Testing strategies increase test performance [17]. So, it can be said that exercise type of questions is solved rather than solving problems in Turkey. In other words, students solve questions which have similar algorithms with the questions they solved in the classroom rather than the problems that they encounter for the first time. This case requires students to solve as many questions as they can in a short time.

High school mathematics curriculum was renewed by Ministry of National Education (MEB) in 2013 in Turkey.

The well-structured activities expected from the teachers concerning the problem solving at the high school mathematics education program have to be designed according to the items mentioned below:
1. The learning environments that are based on the realistic problem solving and the modeling activities as well as on the active participations of the students themselves with the proper knowledge and interest levels of them have to be preferred.

2. The convenient environments where the students can freely make assumptions and generalizations in order to experience the mathematical thinking processes by means of discussing among themselves have to be provided.

3. The depth of the subjects to be run and the teaching-learning processes have to be structured by means of taking into account the being ready situation levels, perceiving and motivations and the personal differences of the students themselves.

4. During the abstraction, generalization, modeling and problem solving activities (and especially in-class communication) the support to be given to the students will not be an understanding of presenting the knowledge directly or dictating on either true or false situations but helping them by means of giving hints to them or fostering them to be directed with the thinking activities.

In the high school mathematics program, problem solving steps are as follows:

- Understand the problem

- Devise a plan

- Carry out the plan

- Controlling the solution

- Generalization of the solution and generating a new problem

One of the situations that the 4th stage covers is "Criticizing the assumptions of the problem itself as well as the related strategies and the alternative solving methods of it". Therefore, the fact that the students discuss the alternative solution methods in the class is an activity expected to be carried out by the teacher himself/herself [14].

How using multiple solution methods for solving problems which is seen as a waste of time from students' perspectives is perceived by teachers constitutes the basis of this study.

\section{Method}

The purpose of conducting this study is to question the opinions of prospective teachers about the ability to produce an alternative solution for a problem. The qualitative research approach requires from researchers to be flexible, restructure the research process according to collected data and follow an approach which is based on induction in both research design and also in the analysis of the collected data [24]. Whether the qualitative study results can be transferred or can be used in other fields depends on the thick 
descriptions of the data which the results are obtained [13].

The research model of this study was a phenomenological study that aims at describing situations without interfering with or changing the situations. This study was designed to seek the answers to the research questions by employing qualitative techniques.

Problem solving trial about a geometry question by using multiple solution methods which lasted a course time was carried out with prospective teachers in terms of having an opinion regarding problem solving with multiple solution methods. Later on, the solutions methods which prospective teachers found was written on the blackboard and discussed. After this practice, five open-ended questions were asked to prospective teachers and their beliefs regarding problem solving were questioned. The five open-ended questions were determined by two associate professors who are experts in the field of mathematics education.

Problem solving trial about a geometry question by using multiple solution methods which lasted a course time was carried out with prospective teachers in terms of having an opinion regarding problem solving with multiple solution methods. Later on, the solutions methods which prospective teachers found was written on the blackboard and discussed. After this practice, five open-ended questions were asked to prospective teachers and their beliefs regarding problem solving were questioned.

\section{The Study Group}

Science and Letters graduates can receive pedagogical training to be teacher at the state high schools since 2010 . The participants of the study had been teachers at any private schools or courses for 3-8 years. However, they wanted to be a teacher at the state high school, therefore they received pedagogical training from a state university.

The study was carried out with 60 prospective teachers. The participants are composed of prospective teachers who were graduated from mathematics department and who are about to finish their pedagogy training in 2014-2015 academic years. The problem solving studies by using multiple methods were carried out for two weeks with prospective teachers and the prospective teachers were asked to think about on this topic. In other words, after the questions of the study had prepared, the participants were provided with the sufficient time for constituting their thoughts on this topic.

\section{Procedure and Data Collection Instruments}

Before the study, a problem solving trial by using multiple solution methods was conducted on a geometry question in one lesson with prospective teachers in terms of producing opinions regarding problem solving by using multiple solution methods. Later on, the solution methods found by prospective teachers were written on the blackboard and they exchanged their opinions through discussing their solution methods. The advantages and disadvantages of sharing different solution methods with each other were asked to prospective teachers. Prospective teachers stated that with the help of problem solving by using multiple solution methods, they discovered new solution methods, recalled the formulas, rules and knowledge that they forgotten and they believed problem solving by using multiple methods will bring advantages in the improvement of their academic knowledge and becoming an expert in their fields. Besides, they added that looking for the different solution methods in classroom and exchanging ideas will provide positive attitudes towards mathematics lessons. Not all the teachers agreed with the opinion that solving problems by using multiple solution methods has advantages and they pointed out the disadvantages. The first thing emphasized by the prospective teachers who were supporting the antithesis was the fact that this activity in which all the solutions methods are questioned, written on the board and later discussed requires plenty of time and for this reason it can only be carried out with highly skilled students. Moreover, they highlighted that low-level students will be confused after they see multiple solutions regarding the questions and they will display negative attitudes towards mathematics lessons.

After this pre-implementation, five structured interview questions which are questioning their beliefs about problem solving by using multiple solution were posed to prospective teachers.

The data was collected by using a questionnaire as a data collection instrument which involved open-ended questions. Five open-ended questions were prepared in this study and the content validity was ensured by taking the opinions of two lectures who are experts in their fields. The opinions of 60 participating prospective teachers on producing alternative solution methods were tried to be taken by asking this five open-ended questions. The questions which were asked to prospective teachers are as in the following:

- Do you believe that solving problems by using multiple solution strategies bring any advantages to teaching mathematics?

- Which of the solution methods of a problem do you present your students in a lesson?

- Do you have any criteria while showing solution methods of a problem? If yes, what are they?

- If you want to present all the solution methods of a problem in an order, in which order will you present them?

- Do you encourage your students on solving problems by using multiple solution methods?

\section{Data Analysis}

The data was collected in written form and classified according to highlighted feature in the responses which have the common ground according to grounded theory data 
analysis from qualitative study methods.

The steps of data analysis as follows:

- Data were examined detailedly

- Similar data content was coded (open coding was used)

- The same codes were categorized

These steps were implemented for each question separately.

The classifications were supported with expert opinions. The reliability in qualitative studies is calculated with the following formula $=$ [Number of Agreement/ (Number of Agreement + Number of Disagreement) x100]. According to this formula, when the agreement is $90 \%$ or over, the desired reliability will be ensured (Miles and Huberman, 1994). Also in our study, the agreement percentage was found as $90 \%$. Besides, the opinions of prospective teachers were tried to be stated frequently in findings section.

\section{Findings}

The answers of the Prospective Teachers for the 1st Question.

$84 \%$ of the prospective teachers who expressed their opinions about solving problems by using multiple solution methods stated the importance of solving problems by using multiple solution method. The participants stated that after students solve a problem, they should be encouraged and motivated to solve the same problem by using a different method. They claimed that solving problems by using multiple solution methods provide students to approach problem from a broader perspective, each solution can be a base for another solution, contribute to the refreshment of the previous knowledge and it will not be realistic to present all the solution methods to all of the students but it is necessary to present as many solutions methods as possible to students. According to this, the skills and situations which solving problems by using multiple solution methods will affect positively displayed in Table 1 . Some of the prospective teachers touched on all the titles stated in Table 1.

Table 1. The Advantages of Solving Problems by Using Multiple Solution Methods

\begin{tabular}{|c|c|c|c|}
\hline Creativity & $\begin{array}{c}\text { Getting } \\
\text { Different } \\
\text { Perspectives }\end{array}$ & $\begin{array}{c}\text { The } \\
\text { Consolidation of } \\
\text { Basic Skills }\end{array}$ & $\begin{array}{c}\text { The Association } \\
\text { between } \\
\text { Concepts }\end{array}$ \\
\hline$\% 90$ & $\% 90$ & $\% 20$ & $\% 40$ \\
\hline
\end{tabular}

The opinions of teachers regarding problem solving by using multiple solution methods appeared as positive $(90 \%)$ and negative $(10 \%)$ answers.

Solving problems by using a couple of different methods will definitely improve creativity.

Having different perspectives brings advantages for students for their lives outside the school.

As different solution methods found by students will give the same result, students can discover the relations and connections between concepts.
In my opinion, finding different solution methods for a problem is important, because students will try to use the solution method that he/she found in other problems. The conceptual and operational skills will be consolidated.

To tell the truth, not all the problems have different solution methods, but it is necessary to present the ones that have. Students can solve the problem by moving from these solution methods in different problems that they will encounter. For this reason, using multiple solution methods while solving problems is a useful method.

The answers of the Prospective Teachers for the 2nd Question.

Prospective teachers said that there will be some difficulties in solving problems by using multiple methods because of the central examinations, however more than one solution method can be presented to students and it will be beneficial for students to know multiple solution methods. On the other hand, they advocated that students should absolutely learn the most practical way. The criteria of the solution methods which were used by prospective teachers and which they need to teach their students displayed in Table 2.

Table 2. The Criteria of the Solution Methods which were preferred by Prospective Teachers

\begin{tabular}{|c|c|c|c|}
\hline $\begin{array}{c}\text { The shortest } \\
\text { and easiest } \\
\text { one }\end{array}$ & $\begin{array}{c}\text { The one which } \\
\text { involves information } \\
\text { about several } \\
\text { concepts }\end{array}$ & $\begin{array}{c}\text { The } \\
\text { original } \\
\text { one }\end{array}$ & $\begin{array}{c}\text { The one which } \\
\text { does not require } \\
\text { a formula }\end{array}$ \\
\hline$\% 100$ & $\% 80$ & $\% 90$ & $\% 20$ \\
\hline
\end{tabular}

Prospective teachers were able to determine more than one criterion. It is seen from Table 2 that prospective teachers pay attention to have their students know the original, the shortest and easiest way. Although they did not mostly prefer solution methods which require using a formula, they stated that students should know them. Only 12 of the prospective teachers stated that they hope students can solve problems without knowing any formulas.

I think students should know the easiest and shortest method. This can be a formula or something that they memorized. As they will take a central examination, in order to be able to make a difference, they should absolutely know the shortest method.

The solution methods in which several concepts are used seem to me creative. If I want to improve my students' creativity, I should present this kind of solution methods.

If there were not a central examination system, I would rather them to find original solutions, however the purpose is to find the result in the shortest time. Therefore, the shortest and easiest methods seem fine to them.

I encourage my students to find original methods, however I cannot do it every time. Because, I have to complete the curriculum and time is not enough to produce original solutions all time.

I will show solution methods in which formulas are being used to my students; however I do not believe that they will remember the formulas later and I do not want them to find 
solutions with memorization.

The answers of the Prospective Teachers for the 3rd Question

Prospective teachers were asked whether they have some criteria for the solution methods. All of the prospective teachers stated their beliefs that there should be some criteria and these criteria should mostly be based on students' academic knowledge. $30 \%$ of the prospective teachers mentioned the curriculum limitations and they expressed that this is also an important criteria.

Table 3. The Criteria that should be considered in presenting solution methods

\begin{tabular}{|c|c|c|}
\hline Readiness Level & Grade Level & Time Limitations \\
\hline$\% 100$ & $\% 100$ & $\% 30$ \\
\hline
\end{tabular}

Prospective teachers underlined that readiness levels (mostly their approaches and attitudes), of the students, their backgrounds about the lesson and their levels are important for solving problems by using multiple solution methods. Some of the prospective teachers claimed that teachers should take the time factor into account for completing the curriculum on time, for this reason, only when they have extra time, they can solve problems by using multiple solution methods.

I think that they will not be able to understand all the solution methods, even though I give all the solution methods to them without considering their level of readiness and grade levels. It is necessary to present multiple solution methods, but presenting complicated solution methods to students whose mathematical skills are low will make them be more disinterested against mathematics.

There is a time limitation. We have to cover the curriculum. For this reason, I try to use multiple solution methods as long as the time allows.

I prefer to spend my time for solving several problems instead of solving a single problem by using multiple solution methods. Students will take nationwide examinations and I want them to sell all type of problems. I believe that they will be more successful, it they know more problem types.

The answers of the Prospective Teachers for the 4th Question.

Prospective teachers were asked that if they want to present all the solution methods of a problem in an order, in which order they will present them and their answers were displayed in Table 4.

Table 4. The Order of Presenting Solution Methods

\begin{tabular}{|c|c|c|}
\hline $\begin{array}{c}\text { From simple } \\
\text { to complex }\end{array}$ & $\begin{array}{c}\text { From the method in which the } \\
\text { most important concept is used } \\
\text { to the least important one }\end{array}$ & $\begin{array}{c}\text { From the known } \\
\text { method to the } \\
\text { original one }\end{array}$ \\
\hline$\% 100$ & $\% 90$ & $\% 90$ \\
\hline
\end{tabular}

All the participants advocated that solution methods should be presented from simple to complex, but most of them also pointed out that the most used concept in geometry problems is the concept of similarity and they asserted that the solution method which is about the concept of similarity should be presented beforehand. Most of the prospective teachers stated their beliefs that original solution methods should be presented by moving from the known solution methods.

I will first present the easiest and simplest method to my students. If I start solving the problem by using a method requiring several operations and concepts, I believe students will get confused.

For example, similarity subject is inevitable for geometry. I can find a solution by using similarity even if I could not remember any other methods. For this reason, I start presenting by using solution methods about similarity first.

I start presenting by using the solution methods which everybody knows. I present the solution methods that nobody knows or rarely known to my students and I ask them to discover original methods.

The answers of the Prospective Teachers for the 5th Question

Prospective teachers were asked how often they want to encourage their students to solve problems by using multiple solution methods. The prospective teachers who answered as 'always' and 'never' constitute the $20 \%$ of the participants.

Table 5. The Frequency of Prospective Teachers for encouraging their students for solving problems by using multiple solution methods

\begin{tabular}{|c|c|c|c|}
\hline Always & Generally & Rarely & Never \\
\hline$\% 10$ & $\% 20$ & $\% 60$ & $\% 10$ \\
\hline
\end{tabular}

6 of the participants said that they believe solving several problems instead of solving a single problem by using multiple solution methods will be more helpful to their students. So, they stated that they are not planning to use problem solving by using multiple solution methods.

Teachers, who are for solving problems by using multiple solution methods in lessons, charted out how this teaching practice will be used:

Teachers should allocate enough time to students so that they can produce different solution methods. Later on if you have a class discussion by writing the solutions on the board, students can come up with different opinions and they can exchange their ideas. If the teacher suggests multiple methods for the solution of the problem in the class, solution methods should be written from simple to complex and students should have an option to choose the method that he/she wants.

The perception style of each student is different. For this reason it is important to employ problem solving by using multiple solution methods. Thus, the student will learn the subject with the help of solution method which is suitable to student's perception. Besides, the connections can be established between solutions.

Problem solving by using multiple solution methods should be employed by considering students' levels Students should see solution methods without depending on a single method and before becoming blunt.

Some of the students understand mathematics lessons 
immediately and some have difficulties in understanding mathematics. I want to know my students' perspectives regarding the problem. Also I want them to develop different perspectives. For this reason, I try to employ solving problems by using multiple solution methods.

The teachers who do not see employing problem solving by using multiple solution methods as necessary advocate their ideas as in the following:

If the level of students is low, it will be enough to solve the problem rather than searching for multiple solutions.

If the teacher writes multiple solution methods on the blackboard, this situation will cause confusion for students.

If the cognitive level of the class is high, maybe the problem can be solved by using several methods, however it is more logical in country where nationwide examination is conducted to solve a lot of problems instead of solving a single problem by using multiple solution methods.

Problems can be solved by using multiple solution methods, but this should be employed by considering the level of students. On the contrary, students cannot acquire basic features and this ends up with negative thing.

\section{Conclusions and Suggestions}

Encouraging students about going beyond patterns and discovering authentic methods provide them to use their imaginations. The fact that students solve questions according to central examination makes them to use the same method. In other words, solving similar questions by using similar methods will become a habit after a while and end up the corruption of creativity.

Human beings shape their beliefs according to facts that they see around them. Bandura (1977) said that beliefs affect behaviours more than [2]. In order to indicate the reasons of the teachers' behaviours, studying their beliefs will be helpful [4]. Teachers are inarguably the most important factor which will help students to go beyond patterns and to improve their creativity and mathematical thinking. Therefore, the teachers' beliefs affect his/her attitudes, the things that he/she will transfer to his/her students and how to guide his/her.

The purpose of this study was to examine the beliefs of prospective teachers about the importance and implementation of problem solving by using multiple solution methods. In accordance with this purpose, it was tired to determine the beliefs of the prospective teachers by examining their beliefs with 5 open-ended questions. Prospective teachers stated that problem solving by using multiple solution methods is important and will contribute to the improvement of students' thinking skills. The asserted that it is necessary to present multiple solution methods to students but when presenting solution methods, it is important to consider the criteria such as "readiness levels", "grade levels" and "effective use of time.

In the study, it was also determined that some prospective teachers believe that it will be more helpful to solve a lot of problems instead solving a problem by using multiple solution methods. Because of the current central examination system in Turkey, they highlighted that finding multiple solution methods is a waste of time and solving almost all the problems will bring advantages to pass this central examination.

Prospective teachers expressed their thoughts as presenting all the possible solution methods in the classroom will not be possible for the non-achievers because this situation will make those students more uninterested towards mathematics.

Problem solving by using multiple solution methods can be an important alternative evaluation technique which can be used by teachers for seeing acquisition level of the subject and whether rules are learnt or not. This situation is parallel with the result stated in [1] being among the criteria about evaluating problem solving by using different methods.

However, the obstacle in front of the problem solving by using multiple methods is see as the central nationwide examination in accordance with the answers of the prospective students. In other words, if the central examination were not conducted as multiple-choice test, prospective teachers would be able to use problem solving by using multiple solution methods. To be able to solve the question by using choices, to find the result by using test techniques and the necessity of completing the examination in a limited time were stated for the reason of this central examination obstacle.

Although conducting university entrance exams which is carried out by Student Selection and Placement Centre (SSPC) through open-ended questions became the main topic of the conversation, prospective teachers did not state their ideas on this topic as it is not clear when this will be actualised. Therefore, although problem solving by using multiple solution methods was stated by Leikin (2009) as an activity which improves creativity, participating prospective teachers indicated that it is difficult to carry out this activity frequently. But, only 6 of the prospective teachers stated that they will never use problem solving by using multiple solution methods. This situation indicates that prospective teachers are open to change and development despite the question type obstacle employed in the central examination. This is a pleasing situation.

\section{REFERENCES}

[1] Baki, A., \& Birgin, O. (2002). Matematik eğitiminde alternatif bir değerlendirme olarak bireysel gelişim dosyasi uygulamasi. V. Ulusal Fen Bilimleri ve Matematik Eğitimi Kongresi Bildiri Kitab1, II, 913-920.

[2] Bandura, A. (1977). Social learning theory. Englewood Cliffs, NJ: Prentice Hall.

[3] Dooley, M. P. (1997). A model of crises in emerging markets 
(No. w6300). National Bureau of Economic Research

[4] Enochs, L. and Riggs, I. (1990). Further development of an elementary science teaching efficacy belief instrument: A preservice elementary scale. School Science and Mathematics, 90(8), 694-706.

[5] Erickson, F. (1973). What makes school ethnography 'ethnographic'? Council on Anthropology and Education Newsletter, 4(2), 10-19.

[6] Gail, M., (1996). "Problem Solving about Problem Solving Framing Research Agenda", Proceedings of the Annual National Educational Computing Conference, Minnesota, 17: 255-261. (ERIC Document Reproduction Service No. ED 398 890).

[7] Ginsburg, H. P., and Baron, J., (1993). Cognition: Children's onstruction of mathematics. In R. J. Jensen (Ed.), Research ideas for the classroom: Early childhood mathematics: 3-21, New York: Macmillan.

[8] Hacısalihoğlu, H. H., Mirasyedioğlu, İ. ve Akpınar, A., (2004) Matematik öğretimi (1. bs.), Ankara: Asil Yayın Dağıtım.

[9] Heilman, E. E. (1998). The democracy of the imagination, the culture and the school: A study of teachers' beliefs. Indiana University. ProQuest Information and Learning Company. UMI Number: 9907338.

[10] Hoy, W.K. \& Miskel, C.G. (2001). Educational administration: Theory, research and practice, 6 th edition. Boston: McGraw-Hill.

[11] Krutetskii, V. A. (1976). The Psychology ofMathematical Abilities in School Children, University of Chicago Press, Chicago

[12] Leikin, R. (2009). Exploring mathematical creativity using multiple solution tasks. Creativity in mathematics and the education of gifted students, 129-145.
[13] Lincoln, Y. S., \& Guba, E. G. (1985). Naturalistic inquiry (Vol. 75). Sage

[14] MEB (2013). Ortaöğretim matematik dersi öğretim programı. Ankara: Milli Eğitim Basımevi

[15] Orton, R. E. (1996). How can teacher beliefs about student learning be justified? Curriculum Inquiry, 26(2), 133-146

[16] Pajares, M. F. (1992). Teachers' beliefs and educational research: Cleaning up a messy construct. Review of educational research, 62(3), 307-332

[17] Samson, F. B., Perez-Trejo, F., Salwasser, H., Ruggiero, L. F., \& Shaffer, M. L. (1985). On determining and managing minimum population size. Wildlife Society Bulletin (1973-2006), 13(4), 425-433.

[18] Schoenfeld, A. H., (1989). "Explorations of students' mathematical beliefs and behavior". Journal for Research in Mathematics Education, 20(4), 338-355.

[19] Skemp, R., (1987). The psychology o f learning mathematics, New York: Penguin Press.

[20] Tertemiz N. ve Sulak, S. E., (2013). The Examination of the Fifth-Grade Students' Problem Posing Skills]" . İlköğretim Online, 12(3), 713-729

[21] Toluk, Z. ve Olkun, S., (2001). İlköğretim Ders Kitaplarının Problem Çözme Becerilerinin Geliştirilmesi Açısından İncelenmesi, X. Eğitim Bilimleri Kongresi, Abant İzzet Baysal Üniversitesi, Bolu

[22] Van De Walle John A.,(1994). Elementary School Mathematics, Virginia Commenralth Universitl, Longman.

[23] Yero, J. L. (2002). Teaching in mind: How teacher thinking shapes education. MindFlight Publishing

[24] Yıldırım, A., \& Şimşek, H. (2006). Sosyal bilimlerde nitel arastirma yöntemleri. Seçkin Yayıncılık 